\title{
ANALOGY, POLARITY AND MORALITY IN SCYTHIAN HIP- PAKE: REFLECTIONS ON HERODOTUS, (HISTORIES 4. 2)
}

This paper has two principal purposes. First, in section 1, I offer some very general points about how we may best understand Greek treatments of Scythian themes. It is argued that the tendency to stress the difference (even polarity) between Greeks and Scythians should be balanced and at least contextualised by consideration of similarities and analogies too. In the second part, it is argued in detail that the milking of horses was by no means strange to Greeks, even though Greeks made much less use of horse milk, and preferred to consume it in liquid form and not as cheese (hippake).

Keywords: Northern Black Sea region, Scythia, Greek, hippake, auloi Herodotus.

\section{GENERAL REMARKS}

In the study of Scythia and Scythians the usual gap or «poor fit» between archaeological data and written evidence is especially troublesome. For, while archaeology concerns the peoples of the northern Black Sea region in a very direct way, our written sources come from a very different environment. The authors of these texts were not only Greeks themselves, but (perhaps more important) were also writing for Greeks. Furthermore, and perhaps most important of all, they and their intended audiences were part of a culture that was far removed from the Black Sea, except in a very few cases. Only rarely did they have or claim to have any direct experience of Scythia or even of the Greek settlements around the Black Sea. This matters enormously, especially because these writers were therefore engaged in a creative (and not just descriptive) process which looked, Janus-like, in two different directions. On the one hand, such writers sought to understand the Scythian world and show it to their audiences and readers, in whatever spirit. On the other hand, however, they had also to create their works in a (broadly Greek and Mediterranean) cultural tradition in which Scythia and Scythians already had a reputation (further, Skrzhinskaya 1998). And that reputation (which might be simple or complex) had been forged and established within their Mediterranean culture (s), often with little or no knowledge or even concern for Scythian «realities». The Greek creation of Anacharsis is a fine example of that process (e. g. Kindstrand 1981; Ungefehr-Kortus 1996; Schubert 2010). The striking fact is that when we begin to have written texts from Greek culture in the archaic period (Homer, Hesiod etc.), we find Scythia and Scythians already embedded in that culture, whether or not the term Scythia or the like is used.

All this is not doubt very inconvenient, especially for those who are not willing or prepared to tackle the many-sided problems of Greek culture. It would certainly be much easier for scholars if they could simply cut bits of information, statements and short sentences from our Greek texts, and then apply them to Scythia and its archaeology. In fact, that has often been the method used by archaeologists in all regions of the ancient world, but there is something obviously and profoundly unsatisfactory about such a method, in which enormous care is taken properly to handle archaeological data, on the one hand, but little or no such care is devoted to understanding the texts which are used to explain its significance and more (my disagreements with Müller 2010 mostly arise from this issue). At the same time, we must be very clear that our ethnic terminology is only helpful and applicable to a limited extent. A familiar problem in Scythian studies is that the term "Scythian» is applied to an extraordinary range of different cultures, across an enormous geographical expanse. Nomadism is often taken to be characteristic of Scythians, but of course there are many kinds and degrees of pastoralist activity that may be termed «nomadism», 
while the inhabitants of the huge settlements, for example, of the wooded steppe (Bel'sk and the rest) were hardly nomads, but are routinely called «Scythians», nevertheless. Geographically, we can hardly be comfortable with a terminology which makes Scythians of peoples who stretch from Centra Europe almost to Japan, and across Central Asia into the Indian subcontinent. This terminology is at root the creation of Greek culture, extended by subsequent scholarship. Already in the fifth century BC, of course, Herodotus showed the weakness of this crude terminology and tried to do better, stressing for example that this was Greek terminology and that Scythian ethnicity was something to be tested and contested in the region itself (Herod., 4. 6 is especially clear). His direct experience of at least a small corner of the region at Olbia helps to explain his attempt to create more nuance in Greek perceptions of Scythia and Scythians. At the same time, he also knew full well, as we too should remember, that Greek ethnicity was also a manysided and complex issue. Athenians, Spartans and many more constituted a range of very different ways of being Greek. Although Herodotus is not much interested in Greeks of the Black Sea (except insofar as they connect with Scythains, his primary concern in Book Four of his Histories), he is careful to indicate when the views and beliefs of Black Sea Greeks differ substantially from those of Greeks elsewhere, as notably in their treatment of Heracles (esp. Herod., 4. 8-10). It is worth stressing that Greeks not only differed among themselves in very many ways, but were also prone to mutual disdain and outright hostility, both in the Greek mainland and beyond, as in the Black Sea itself.

Much of this may seem obvious, but the truth is that a great deal of scholarship goes about its business in complete neglect of these fundamentals. Complexity may be unwelcome and inconvenient, but any study of the ancient world that seeks a depth of understanding must embrace and work with its reality. The habit of contrasting Greek and Scythian is almost a founding principle of ancient studies, often enshrined in institutional and departmental divisions. There are good reasons for this, but we must also be aware that we are reproducing in this simple, polarised contrast the broadly Greek perception that was already unsatisfactory (if also inescapable) for Herodotus, who observes the interplay between Greeks and Scythians in a range of ways, including the existence of Greek Scythians (Herod., 4. 17, the Callippidae) and the gone-native Greeks of Gelonus (Herod., 4. 108-110). He shows us a world in which the polarity of Greek and Scythian may be useful for interpretation and discussion, but which is in reality an environment of interaction and exchange, even if that might entail friction (further, Braund 2008). Famously he shows Scythian hostility to the adoption of the cults of Dionysus and Cybele, apparently to illustrate a broader Scythian resistance to Greek culture (Herod., 4. 76). However, it is worth stressing that these were also cults known among Greeks too (Munn 2006) as dangerous arrivals from outside (as Herodotus knew). As, for example, Euripides shows in his Bacchae, resistance to Dionysiac cult was key to its very identity: this was a god whose arrival was met with a mixture of suspicion, hostility and prurience among Greeks, not least because of the nature of his rites. Here and elsewhere, the god uses his overwhelming power (which includes much more than simple force) to undermine, ridicule and punish the human powers that fail to embrace him. At Athens, the fact that this and similar tales (notably about Thracian Lycurgus: Braund 2001; Shaub 2007) were celebrated at the very festivals of Dionysus, shows clearly enough how these notions of human resistance and divine conquest were integral to Dionysiac cult in the city. At Olbia, this tale of Scythian resistance was no doubt part of the civic treatment of Dionysus, as it was in Athens and elsewhere across Greek culture (further Braund 2008). In one sense, therefore, Dionysus' cult marks a gulf between Scythians and Greeks, especially as understood at Olbia, but in a way that might be imagined entirely amomg Greeks (as at Euripidean Thebes), while, at the same time, the examples of Scyles and Anacharsis (on Cybele) show how ethnicity need not be a conclusive factor in human-divine interactions. Clearly, these very Olbian stories show the importance (not least for the Olbiopolitans) of the contrast and distinction between Greeks and Scythians, but even while they do that they also illustrate the limited importance of that same distinction. There was also the considerable extent to which a neglect of Dionysus might be much less problematic among nonIonian Greeks. The awkward fact is that much-bruited polarity between Scythian and Ionian (whether Olbia or Athens) was accompanied by a good deal of analogy between Scythian and Dorian (as Herodotus saw: Braund 2004).

\section{MORALITY, THE AULOS AND HIPPAKE}

With these broad problems very much in mind, we may proceed to the much-discussed phenomenon of hippake. It is not my concern here to repeat all that we know about the term and the substance. Instead, I wish to make a single point about the tendency (ancient and modern) to identify hippake as a key feature of the polarity of Scythians and Greeks. In doing so, it is my intention also to illustrate by this example the limited value of such polarised thinking as well as the relevance of what has been called the «Scythian mirage» (Lévy 1981; Ivanchik 1999).

The Scythians' special relationship with horses appears everywhere in Greek ideas and statements about them. Herodotus, for example, affirms that Scythian (men) are all mounted archers. There can be no doubt about his Greek: he specifies that they are all archers on horseback (Herod., 4. 46). The claim is a little strange, not only because Scythian art seems to show us Scythians fighting on foot (as the famous comb from Solokha, for one example), 
but also because his own account seems to suggest more than mounted archers, as when he describes the Scythians fighting the slaves' sons (4. 3) or drawn up for battle against Darius (Herod., 4. 134). Therefore, there is no reason to suppose that Herodotus is simply mistaken in seeing all Scythians as mounted archers. The more likely explanation is that he means that Scythians in general have the ability and potential to fight as mounted archers, even though (as archaeology demonstrates) they may fight in other ways too. It is perhaps unreasonable to press our author too hard about his use of «all», either here or at 4. 2, when his statement that Scythians blind all their slaves must be understood with obvious exceptions made, e. g. for slaves to be sold on to Greeks and others.

It is also likely that Herodotus' possibly-misleading statement about equestrianism arises from the more fundamental contrast between the role of the horse (and also the archer: Chernenko 1981; Lissarrague 1990) in Greek and Scythian society. While the horse was a central and widespread feature of Scythian society and economy, in Greek society it was the characteristic possession of the most wealthy and powerful. In short, while every Scythian might have a horse (at least in principle), every Greek certainly did not and could hardly dream of it. For Greeks (including Herodotus and his readers) it was a profoundly strange feature of Scythian society that horses were commonplace and not the markers of privilege, except in the sense that wealthy and powerful Scythians might have more and better horses than their poorer counterparts. Greeks understood the economics of keeping horses, so that Herodotus does not quite take the trouble to explain that horse-keeping too was part of what he presents as the Scythian development of a lifestyle that was peculiarly appropriate to the steppe environment, where horses were also of course key to the mobility that he does trouble to stress (Herod., 4. 46). It was obvious enough to any Greek (and need not be said) that the difference between Greeks and Scythians in the matter of horse-keeping was a consequence of the different availability of grass in the places where these two peoples tended to live. The Hippocratic Airs, Waters, Places expands at leg on these matters precisely because of its environment-centred agenda and its tendency to compare north (Scythia) and south (Libya) with Greece, on which more below. On the Greek mainland, good grass - and so food for horses - was in limited supply and so the preserve of the wealthy (further, Xenophon, Art of horsemanship), but in Scythia grass was everywhere. In broad terms (for we are dealing in generalities), the different social significance and presence of horses among Greeks and Scythians was part of a more fundamental difference in environment (such as stressed in the Airs, Waters, Places) and in the nature of land-use and ownership, about which Greeks have little in detail to say on Scythian practice (though generalities were not rare: e. g. Strabo, 7.3.7).
In Scythia (probably even more than among Greeks) it was also the decoration of horses that set individuals apart. This included forms of decoration that were by no means normal to Greek culture, most strikingly the suspension of human scalps and even the conveyance of reconstructed bodies of enemies (Herod., 4.7 etc.). We may see such ghastly dйcor as the display of conquest and power that would be expressed differently among Greeks, not least in the public buildings and art which were alien to Scythian culture. One suspects that the display of victory (and the status that came with it; cf. Herod., 4. 66) was all the more striking when the vehicle of display (the horse) was also the means of victory. At the same time, however, the important point for the present discussion is that Greeks were also in the habit of decorating their horses so as to display their wealth and status (Moore 2004; Griffith 2006; Mrva-Montoya 2013). In short, Greeks shared in broad tendencies in Scythian society, even though the ways in which these tendencies manifested themselves were different, and sometimes very strikingly so. We see this again in sacrifice, for Herodotus reports that the horse was the animal most frequent offered for sacrifice among Scythians (Hdt. 4. 61), while among Greeks horse sacrifice was also to be found, but far less commonly (Burkert 1983). We may wonder how many of the horses sacrificed by Scythians were for the deity whom the Scythians, it seems, equated with Poseidon (Hdt. 4. 59). A Greek view of the horse's importance among Scythians might very well include thoughts and interpretation of Scythian belief in terms of Poseidon. For in the Greek context Poseidon was exceptional as the only one of the principal gods to be imagined and depicted on horseback (among lesser deities, one may consider the Dioscuri, for example). However, his associations with horses in Greek culture are much more extensive than that (Eaverly 1995, s. 56-59). Presumably the Scythian elite became aware of the Greeks linkage of Poseidon to the horse, as well as other aspects of nature, including earthquakes and of course the sea. We are left to reflect upon the Greek-Scythian interactions that may lie behind the decision of rich Scythians to decorate horses and other key possessions with fish (as with the famous frontal from Solokha; cf, the shield (?) that bore the fish found in the treasure at Vettersfelde). Are we indeed seeing here such interaction (clearer with Achilles, for example), or did Scythians have their own, independent conceptions of the appropriateness of a fish to a horse, with or without a deity that looked in some sense like Poseidon? We may ask the question, but this is not the place to go further into Scythians beliefs (further, Bessonova 1983; 2004).

These are enormous questions and uncertainties, within which we must try to understand Scythian culture in its many aspects, as well as Greek perceptions of it. However, even a superficial glance at these issues provides a useful context for the matter of hippake not only in Greek perceptions of Scythians, but also in Greek medical theory and practice. 
At the same time, all this tends to explain the apparently strange way in which Herodotus chooses to approach the Scythians and Darius' failed attempt to conquer them. For, after briefly reminding his audience of earlier events that he had described in his first book (the short Scythian conquest of Asia), Herodotus immediately raises the matter of hippake. We are now in a position to understand that he does this (at least in substantial part) because the Scythians were known in Greek culture for their milking of horses, and all that attended that process. Already in Homer and Hesiod, they are horse-milkers (Homer does not call them Scythians: further Ivanchik 1999). By introducing in this way Scythian culture as a whole (not simply the specific tale of conquest in his first book), Herodotus began his lengthy disquisition from a point with which his Greek audience was broadly familiar, before launching into a mass of much less familiar and sometimes appalling detail. Here at 4. 2 Herodotus has brought together the familiar Scythian horse-milking and his earlier conquest-narrative by setting slaves at the centre of his picture, and the reported Scythian habit of blinding all slaves «because of the milk». Immediately we recall the cruelty of Scythian rule in Asia, and the mutilation of slaves may prepare us also for the dissection to come. Meanwhile we may (like many scholars) initially be puzzled by the connection between slave-blinding and milk. As the text unfolds, however, we find that Herodotus has quietly opened one of his main themes in his account of Scythia, namely that Scythians are pastoralists (not agriculturalists) and, by extension, that pastoralism has different requirements. In this pastoral world blind slaves are useful in a way that was hard to predict for an agriculturalist.

To milk a horse is far more difficult than to milk a cow, sheep or goat, for the animal does not release its milk easily. Different cultures have developed their own methods to meet this problem, among which the use of bone pipes, as described by Herodotus is hard to parallel (West 1999, who rightly observes that discoveries of bone pipes need have no link to milking). It seems an awkward method. Stephanie West has drawn important attention to the fact that other nomads find it sufficient simply to blow into the mare, without the use of such a pipe (West 1999). In Mongolia I have witnessed another simple method, which entails bringing the foal close to the horse and letting it feed a little before collecting the bulk of the milk in a bucket, unknown to the mother. Had Herodotus witnessed the use of a pipe? Or had he been told of it, perhaps orally in Olbia, for example, or by some written account. We can never know, but two considerations may lead us to doubt that Herodotus had seen the process. First, the simple fact that, although he had conversations with Scythians and those who knew of Scythians, and had also read about the region and its cultures, he does little to suggest that he had spent much time among Scythians themselves. There is only any hint of that in his treatment of Exampaeus, not so far from Olbia. Second, it may very well be important that the pipe is compared with an aulos. Especially so, since the comparison is rather otiose: there is only one shape that a bone pipe can really take, so that menton of the aulos is unnecessary. Moralism may be the key to grasping its inclusion here. For this musical pipe was the most characteristic instrument of the Greek symposium. For that very reason there was a moralistic tendency among Greeks to reject the aulos as one of the inappropriate aspects of symposium culture (further, Wilson 1999). Scythians were brought into that discourse, both as examples of a different symposium culture and as individuals (most often Anacharsis) who explicitly reject Greek forms of the symposium. We may recall the tale of the Scythian king Ateas who preferred the neighing of his horse to the best aulos melodies (Gardiner-Garden 1989, s. 33). At the same time, all this may also be understood as part of the complex Scythian relationship with Dionysus and wine, which should be understood as more a matter of sobriety than of drunkenness (Braund 2008). Again these are enormous matters, but the key point for the present discussion is that Herodotus' dubious report of the Scythian use of pipes for milking might have arisen out of the quite common notion that they rejected Greek symposium culture, very possibly a (doubtless Greek) claim that Scythians used their pipes not for entertainment at symposia, but for milking their horses.

A further matters of importance arises from this opening of Book Four: the use of blind slaves. Both close attention to Herodotus' Greek (well expressed in Russian at $S C$ 1. 10) and a moment's reflection on practicalities show that he does not mean - as many have thought (even Thomas 2000, p. 57-9; but not West 1999, p. 78) — that blind slaves were used to insert bone pipes into mares, nor to collect the milk. To do these jobs the ability to see was surely crucial: while a congenitally blind person might manage well, a blinded slave was unlikely to be sufficiently dexterous to insert a pipe into even the most docile of horses. Moreover, Herodotus is explicit: the blind slaves are given the job that follows, which involves no great skill and a great deal of mundane and repetitive labour. The Scythians themselves extract the milk and then place (their new blindness made movement difficult) the blind slaves - as if they were machines - in positions where they can agitate it. It is only these wretched individuals whom our author describes as blind, while the Scythians are the milkers. The second matter of importance is the explanation which Herodotus seems to attribute to the Scythians. It has been noticed that their reported explanation of how inflation helps milking accords with contemporary Greek medical science (Thomas 2000, p. 59). That should not surprise us overmuch. In Herodotus' view the Scythian engagement with nature that has produced the Scythian pastoral lifestyle, is a matter of intellectual discovery (Herod., 4. 46), as are particular aspects of that lifestyle, notanly 
the way in which Scythians can make an ox «cook itself» (Herod., 4. 61). While Scythians may well be considered «untaught» (as by Herodotus at 4 . 46), it does not follow that they are stupid or intellectually weak. The point is that through experience they have developed a strong understanding of nature, especially in the aspects of nature that matter to them, which include the processing of milk. Anacharsis himself is nowhere said to have been taught his wisdom: his is a wisdom that derives from his Scythian culture, which has itself been developed through intelligent experience of the natural world of Scythia.

We should also observe that Herodotus does not talk of hippake. His main concern is not the processing of the milk into hippake, but rather the way in which blinded slaves can contribute to the Scythian economy. We should not infer that the name hippake was unknown or strange to Greeks: thanks to an Aeschylean fragment (fr. $198 \mathrm{~N}$ ) preserved by Strabo (7.3.7), we know that the word hippake was used on the Athenian stage in the Prometheus trilogy that is now plausibly dated around 440 BC on literary and historical grounds. Strabo gives no indication that the word was explained on stage, so that with some caution (for we have scant context for the fragment, and Airs 18 explains the term; cf. De morbis 4 . 51) we may infer provisionally that the word hippake was well enough known in Athens of the mid-fifth century. Of course, Athens was an exceptionally international city, and around 460 , some two decades before the play, there was no doubt a new interest and debate about Scythians when the democracy decided to establish a corps of Scythian slaves to enforce public order under the direction of the appointed magistrates (further, Braund 2006). In that context it is especially interesting that the Aeschylean fragment - «eaters of hippake, well-ordered Scythians» - brings together the Scythian consumption of hippake and their eunomia, which had already been brought into a tragedy of Aeschylus in 458 (Eumenides, 703-706; cf. Bäbler 2005). Strabo was writing many years later, and clearly took into account much that had intervened since the fifth century, but we should at least observe that he builds this fragment into a highly moralistic model, in which the Scythians' consumption of hippake seems to be part of a larger notion of the Scythians as an attractively simple people (further, Lévy 1981). Herodotus makes very clear his rejection of attempts to idealize the Scythians (esp. 4. 46), so that, if hippake might evoke such notions for Greek readers, we may well understand his decision not to use the word: there is nothing very ideal about this blinding of slaves. However, there is also the more simple point that even after the labours of these slaves (his subject) there was presumably at least a removal and drying process (by others than the blind slaves) before the sediment in the milk might properly be called hippake (as De morbis specifies: quoted below).

Accordingly, because Herodotus had only a passing concern with the separation process at the heart of hippake-production, we find the most detailed account of that process elsewhere in Greek literature, in the medical tradition of the Hippocratic school. Here too, however, the processing of the milk is not the central concern. It is very much a means by which the author seeks to explain what he considers a similar process in the human body. The fact that Scythian milkprocessing is introduced to give a better access and understanding to the Greek reader can only confirm our suggestion that Greeks were broadly familiar (no doubt to varying extents) with the Scythian working of milk that created hippake. The key text is Hippocrates, De morbis 4. 51:

It is like what the Scythians make from horse milk. For they pour the milk into wooden vessels and agitate it. The disturbed milk froths and separates, and the fat - which they call butter (literally, bouturon $=$ "cow-cheese») - stands apart at the surface as it is lighter. The heavy and thick part lies beneath: they take that away and dry it. When it has formed a solid and dried, they call it hippake. The whey of the cheese is in the middle. Thus also in a human, when all the humour in the body is disturbed...

Scholars have been as agitated as the milk about the possible linkage between Herodotus and this passage. We may be sure at least that they are independent on the principal matter of hippake, for Herodotus envisions two kinds of product from the milk, while the more detailed medical account shows three. The problem is, of course, that the two texts have very different concerns: while Herodotus seeks to explain how blinded slaves may be useful, the medical text seeks to explain the workings of the human body by reference to Scythian treatment of milk. Of course the Hippocratic reference to Scythian practice is idiosyncratic in any event, but it would be wholly remarkable but for the fact that (as we have begun to see) Scythian horse-husbandry and its products were broadly familiar in Greek culture. Moreover, among Greeks inclined to the study and practice of medicine, Scythians had a very special importance. It was their geographical position that mattered above all. Another Hippocratic text shows us a geographical model of the world which had three key locations, namely Scythia in the north, Libya in the south and (where Delphi might have had a claim) in the centre Delos (Hip. Prognost. 25). A glance at the Airs shows the Hippocratic concern not only with the medical issues over climate in Scytia, but also the counterpointing of Scythia and Libya, with Greece as a medium position. We should not be surprised to find there both brief mention of hippake and a broader interest in the medical consequeces of the horse-riding that was key to Scythian society. For the medic interested 
in different lifestyles and environments and the relationships between man and nature therein, Scythians were of prime interest.

Crucially, however, we must also understand that the milking of horses and the consumption of such milk was not alien to Greek culture. The Scythians were not the only users of horse milk. Nor was it outside Greek medical practice. As was stressed in the first part of this discussion, the difference between Scythian culture and the cultures of Greeks (whether Athenian, Spartan or otherwise) was not the simple polarity that has often been claimed (notably by Hartog 1988), whereby Scythian culture and practice were the opposite of Greek counterparts (usually Athenian in Hartog 1988). Rather the difference may be more a difference of degree and extent than one of polarityas was stressed in the first part of this discussion. As we saw, Greeks knew all about horses in their own way, while the social significance etc of horses was different for them than for Scythians. We should not be surprised that Greeks might milk horses, for they did — but not in the way reported of Scythians by Herodotus (where explanation suggests an alien method). The Greek medical tradition mentions the use of horse milk as a curative, while it also suggests direct knowledge of hippake, notably by Dioscorides $(2.71-2)$, who notes its nutritious qualities and sets it beside the cheese made from the milk of cows, sheep and goats. Dioscorides also shows some interest in the separation process that occurs with those other milks, wherein intensive agitation was not usual (ibid.). Meanwhile, Aristotle includes horse-milk in his exploration of different kinds of milk, with the isolated detail that horse milk was added to Phrygian cheese, presumably before it had formed as cheese (Arist. NA 522a). Horse milk is recommended for treatment of the womb (Hippocrates De mulierum affectibus $1-3$. 222). The Hipocratics knew that horse and donkey milk pass through the body quite easily ( $\mathrm{On}$ diet 1-4. 41) and they recommend it for internal problems (de affectionibus interioribus passim). Most interesting, however, is the Hippocratic recommendation to drink about a litre of uagitated horse milk» each morning (de affectionibus interioribus, 3). The terminology repeats the agitation of horse milk in De morbis, quoted above. However, there is no suggestion that the agitationprocess goes so far as to create hippake and the rest. The Scythian process was labour intensive and was not wanted: the agitated milk was to be drunk, probably under the name oxygala (Hesychius s.v. hippake, quoting Theopompus, perhaps with regard to Ateas: Gardiner-Garden 1989). However, this agitated horse milk among Greeks takes us strikingly close to the Scythian practice, even so. The recommendation suggests that a large quantity of horse milk might be available to the patient, and agitation of the milk was at least a step in the direction of the Scythian process that created hippake. This text, perhaps above all others, illustrates how difference between Greek and Scythian cultures might entail analogy as well as polarity: again, the distinction is a matter of degree. Greeks shared with Scythians an awareness of the nutritional and curative benefits of horse milk. Indeed, there is evidence that Greeks might regard Scythians as especially wise in matters of digestion and purging (e. g. Plutarch, Mor. $148 \mathrm{c}-\mathrm{e})$. At the same time, however, hippake was nevertheless a Scythian foodstuff. It may be that some Greeks made cheese from horse milk, with all the labour that the Scythians deployed in the persons of their blind slaves, but there is no real evidence of that. It was Scythian culture, we are told, that took the large final step from agitating horse milk to producing hippake, which is regularly characterised as a Scythian cheese (Airs 18; Theophrastus, HP 9. 13; Hesychius s.v. hippake). Of course, the word hippake is unquestionably Greek. But that shows us nothing more than the regular Greek habit of preferring to use Greek terms wherever possible. After all, the very name "Scythians» seems to have been a Greek preference: Herodotus tells us that the Scythians themselves did not use the term (Hdt., 4. 6). It is unlikely that Scythians used the term hippake either, except perhaps in their dealings with Greeks. It is a pity that we are not told what the Scythians called their cheese, though Hesychius' lexicon lists a word - bormos — which we might take to be of Scythian origin and which some (he says) understood to mean hippake. Nor are we told of any trade in cheese between Scythians and the Greeks of the Black Sea, nor yet trade in horse milk. Given the medical benefits of these foodstuffs, some exchange is entirely possible.

\section{ЛITЕРАТУРА}

Бессонова, С. С. 1983. Религиозные представления скифбов. Киев: Наукова думка.

Бессонова, С. С. 2004. Крылатый конь - гиппокамп - морской конек и скифский Посейдон. Cmaрожитності степового Причорномор'я і Криму, 11, c. $25-30$.

Иванчик, А. И. 1999. Млекоеды и Абии Иллиады. Гомеровский пассаж в античной литературе и проблемы возникновения идеализации скифов. В: Подосинов, А. В. (ред.). Северное Причернолорье в античности: вопросы источниковедения. Москва, c. 7-45.

Скржинская, М. В. 1998. Скифби глазали эллинов. Санкт-Петербург.

Черненко, Е. В. 1981. Скифбские лучники. Киев: Наукова думка.

Шауб, И. Ю. 2007. Миф, культ, ритуал в Севернол Причернолорье VII-IV вв. Санкт Петербург.

Bäbler, B. 2005. Bobbies or boobies? The Scythian police force in classical Athens. In: Braund, D. (ed.). Scythians and Greeks. Exeter.

Braund, D. 2001. Palace and polis: Dionysus, Scythia and Plutarch's Alexander. In: Nielsen, I. (ed.). The royal palace institution in the first millennium $B C$. Danish School at Athens, p. 15-31. 
Braund, D. 2004. Herodotus' Spartan Scythians. In: Tuplin, C. (ed.). Pontus and the outside world. Leiden, p. $25-41$.

Braund, D. 2006. In search of the creator of Athens' Scythian archer-police: Speusis and the Eurymedon Vase. Zeitschrift für Papyrologie und Epigraphik, 156, p. 109-113.

Braund, D. 2008 Scythian laughter: conversations in the northern Black Sea region in the fifth century BC. In: Guldager, P. (ed.). Cultural interactions in the Black Sea region in antiquity. Aarhus, p. 347-368.

Burkert, W. 1983. Homo necans. Berkeley.

Eaverly, M. 1995. Archaic Greek equestrian sculpture, Michigan.

Gardiner-Garden, J. 1989. Ateas and Theopompus. Journal of Hellenic Studies, 109, p. 29-40.

Griffith, M. 2006. Horsepower and Donkeywork: equids and the ancient Greek imagination. Part Two. Classical Philology, 101, p. 307-358.

Hartog, F. 1988 The mirror of Herodotus. Berkeley.

Lévy, E. 1981. Les origins du mirage scythe, Ktema 6, p. 57-68.

Lissarrague, F. 1990. L'autre guerrier, Paris.

Moore, M. B. 2004. Horse care as depicted on Greek vases before 400 BC. Metropolitan Museum Journal, 39 , p. 35-67.

Mrva-Montoya, A. 2013. Learning from dead animals: horse sacrifice in ancient Salamis and the Hellenisation of Cyprus. In: Johnston, J., Probyn-Rapsey, F. (eds.). Animal Death. Sydney, p. 114-122.

Munn, M. H. 2006. The Mother of the Gods, Athens, and the tyranny of Asia. Berkeley.

Schubert, C. 2010. Anacharsis der Weise. Tübingen.

Ungefehr-Kortus, C. 1996. Anacharsis, der Typus des edlen, weisen Barbaren. Frankfurt am Main.

West, S. 1999. Introducing the Scythians: Herodotus on Koumiss (4.2). Museum Helveticum, 56, p. 76-86.

Wilson, P. 1999. The aulos in Athens. In: Goldhill, S., Osborne, R. (eds.). Performance culture and Athenian democracy. Cambridge, p. 58-95.

\section{REFERENCES}

Bessonova, S. S. 1983. Religioznye predstavleniya skifov, Kiev: Naukova dumka.

Bessonova, S. S. 2004. Krylatyy kon'- gippokamp morskoy konek i ckifskiy Posejdon. Starozhitnosti stepovo Prichornomor'ya i Krimu, 11, s. 25-30.

Ivanchik, A. I. 1999. Mlekoyedy i Abii Iliady. Gomerovskiy passazh $\mathrm{v}$ antichnoy literaturye i problemy vozniknoveniya idealizatsii skifov. In: Podosinov, A. V. (ed.), Severnoye Prichernomor'ye $v$ antichnosti: voprosy istochnikovedeniva. Moskva, s. 7-45

Skrzhinskaya, M. V. 1998. Skifiya glazami ellinov. SanktPeterburg.

Chernenko, E. V. 1981. Skifskiye luchniki. Kiev: Naukova dumka.

Shaub, I. Yu. 2007. Mif, kul't, ritual v Severnom Prichernomorye VII-IV vv. Sankt-Peterburg.

Bäbler, B. 2005. Bobbies or boobies? The Scythian police force in classical Athens. In: Braund, D. (ed.). Scythians and Greeks. Exeter.

Braund, D. 2001. Palace and polis: Dionysus, Scythia and Plutarch's Alexander. In: Nielsen, I. (ed.). The royal palace institution in the first millennium BC. Danish School at Athens, p. 15-31.

Braund, D. 2004. Herodotus' Spartan Scythians. In: Tuplin, C. (ed.). Pontus and the outside world. Leiden, p. 25-41.

Braund, D. 2006. In search of the creator of Athens' Scythian archer-police: Speusis and the Eurymedon Vase. Zeitschrift für Papyrologie und Epigraphik, 156, p. 109-113.

Braund, D. 2008 Scythian laughter: conversations in the northern Black Sea region in the fifth century BC. In: Guldager, P. (ed.). Cultural interactions in the Black Sea region in antiquity. Aarhus, p. 347-368.
Burkert, W. 1983. Homo necans. Berkeley.

Eaverly, M. 1995. Archaic Greek equestrian sculpture. Michigan.

Gardiner-Garden, J. 1989. Ateas and Theopompus. Journal of Hellenic Studies, 109, p. 29-40.

Griffith, M. 2006. Horsepower and Donkeywork: equids and the ancient Greek imagination. Part Two. Classical Philology, 101, p. 307-358

Hartog, F. 1988 The mirror of Herodotus. Berkeley.

Lévy, E. 1981. Les origins du mirage scythe. Ktema 6, p. 57-68.

Lissarrague, F. 1990. L'autre guerrier. Paris.

Moore, M. B. 2004. Horse care as depicted on Greek vases before 400 BC. Metropolitan Museum Journal, 39, p. 35-67.

Mrva-Montoya, A. 2013. Learning from dead animals: horse sacrifice in ancient Salamis and the Hellenisation of Cyprus. In: Johnston, J., Probyn-Rapsey, F. (eds.). Animal Death. Sydney, p. 114-122.

Munn, M. H. 2006. The Mother of the Gods, Athens, and the tyranny of Asia. Berkeley.

Schubert, C. 2010. Anacharsis der Weise. Tübingen.

Ungefehr-Kortus, C. 1996. Anacharsis, der Typus des edlen, weisen Barbaren. Frankfurt am Main.

West, S. 1999. Introducing the Scythians: Herodotus on Koumiss (4.2). Museum Helveticum, 56, p. 76-86.

Wilson, P. 1999. The aulos in Athens. In: Goldhill, S., Osborne, R. (eds.). Performance culture and Athenian democracy. Cambridge, p. 58-95.

\section{Д. Браунд}

\section{АНАЛОГІЇ, ПОЛЯРНІСТЬ І МОРАЛЬ У СКІФСЬКОМУ СЮЖЕТІ ПРО ІППА- КУ: ВІДОБРАЖЕННЯ У ГЕРОДОТА, ICTOPIЯ, 4.2}

Ця стаття переслідуе дві основні мети. По-перше, в розділі 1 , я пропоную кілька загальних зауважень про те, як найкраще зрозуміти античні джерела, що стосуються скіфрських тем. Стверджується, що тенденція підкреслювати різницю (навіть полярність) між греками і скіфами повинна бути збалансованою i, на крайній випадок, контекстуалізована шляхом розгляду подібностей і аналогій. У другій частині детально розглядається той фокт, що доїння коней аж ніяк не було дивним для греків, хоча греки набагато менше використовували кінське молоко i вважали за краще споживати його в рідкій формі, а не як сир (іппаку). З'ясовуеться, що дуже майстерний опис Геродота в його повідомленні про Скіфрію (Herod., 4. 2) за допомогою виробництва іппаки був направлений на воскресіння традиційних грецьких знань (ніби непотрібних) скірів i, більш конкретно, пов'язаний з моралізуванням і ідеалізуванням частин цього «знання». Порівняння трубочок, які використовуються скіфрами (а не осліпленими рабами), щоб змусити коней давати молоко, з авлосами можна зрозуміти як ключ до цього моралізаторського підходу, в який сам Геродот заклав подвійність (особливо Herod., 4. 46).

Ключові слова: Північно-Причорноморський регіон; Скіфія, греки, іппака, авлос, Геродот.

Одержано 15.03.2018

БРАУНД Давид, доктор, продесор університету Ексетера (Великобританія), d.c.braund@exeter.ac.uk. BRAUND David, Doctor, Professor at the University of Exeter (UK), d.c.braund@exeter.ac.uk. 